\title{
PELAKSANAAN TUGAS PEMBIMBING KEMASYARAKATAN DALAM PROSES DIVERSI ANAK YANG BERKONFLIK DENGAN HUKUM DI BALAI PEMASYARAKATAN KELAS I MEDAN
}

\author{
Ica Karina \\ Fakultas Hukum Universitas Katolik Santo Thomas, Medan, Indonesia \\ Email : ichakarina14@gmail.com
}

\begin{abstract}
ABSTRAK
Pembimbing kemasyarakatan adalah petugas pemasyarakatan pada Balai Pemasyarakatan yang melakukan pembinaan pada warga binaan Pemasyarakatan di luar kewenangan Lapas. Pada proses peradilan anak, pembimbing kemasyarakatan bertugas untuk membuat suatu laporan hasil penelitian kemasyarakatan (LITMAS). Penelitian kemasyarakatan ini berfungsi untuk mengetahui lebih dalam latar belakang kehidupan sosial anak baik ekonomi, pendidikan, keagamaan dan interaksi sosialnya. Fungsi Pemidanaan tidak lagi sekedar penjeraan tetapi juga merupakan suatu proses rehabilitasi dan reintegrasi sosial Warga Binaan yang ada di dalam lembaga pemasyarakatan. Dalam penelitian ini menunjukkan bahwa tugas Pembimbing Kemasyarakatan dalam pembuatan penelitian kemasyarakatan dan pendampingan anak yang berkonflik dengan hukum selaku tersangka / terdakwa dalam proses peradilan pidana anak, dan untuk tersangka dewasa dalam tindak pidana tertentu serta LITMAS untuk kepentingan perawatan tahanan dan pembinaan narapidana menunjukkan keterlibatan Pembimbing Kemasyarakatan sejak awal proses hukum hingga kembalinya seorang narapidana dan anak didik pemasyarakatan kepada masyarakat. Dalam pelaksanaannya pembimbing kemasyarakatan Kelas I Medan mempunyai tugas dan fungsi, antara lain tugas pokok pembimbing kemasyarakatan Bapas Kelas I Medan adalah memberikan bimbingan kemasyarakatan atau pengentasan anak sesuai dengan peraturan perundang-undangan yang berlaku dan melaksanakan pembinaan, bimbingan dan pengawasan terhadap klien di luar Lembaga Pemasyarakatan.
\end{abstract}

Kata Kunci :Pembimbing Kemasyarakatan, Diversi, Anak Yang Berkonflik dengan Hukum

\begin{abstract}
Community advisors are correctional officers at the Correctional Center who provide guidance to residents assisted by correctional facilities outside the authority of prisons. In the juvenile justice process, community supervisors in making reports on the results of community research (LITMAS). This social research serves to take a closer look at the background of children's social life in terms of economy, education, interactions and social interactions. The function of criminalization is no longer just a deterrent but also a process of social rehabilitation and reintegration of the Assisted People in prisons. In this investigation, it shows that the task of Community Guidance in making social research and assisting children in conflict with the law as suspects / defendants in juvenile criminal justice processes, and for adult suspects in certain criminal acts and LITMAS for the benefit of treating prisoners and coaching prisoners shows Community Guidance since the beginning Pelaksanaan Tugas Pembimbing Kemasyarakatan Dalam Proses Diversi Anak Yang Berkonflik Dengan Hukum di Balai Pemasyarakatan Kelas 1

Oleh : Ica Karina


of the legal process until the return of a prisoner and correctional protege to the community. In its implementation, the Class I Medan social adviser has duties and functions, including the main task of the Bapas Class I Medan social adviser, which is to provide community guidance or alleviation of children in accordance with the invitation regulations who carry out and carry out coaching, guidance and supervision of clients outside the Penitentiary.

Keywords: Community Guidance, Diversion, Children in Conflict with the Law

\section{A. PENDAHULUAN}

Sistem Pemasyarakatan merupakan perlakuan terhadap warga binaan berdasarkan Pancasila. Dengan mendasarkan kepada falsafah negara, pelaksanaan Sistem Pemasyarakatan sejalan dengan nilai-nilai yang terkandung dalam semua sila Pancasila, sehingga tujuan yang hendak dicapai dapat terlaksana. ${ }^{1}$ Adanya pembinaan bagi narapidana di dalam Lembaga Pemasyarakatan tidak terlepas dari sebuah dinamika, yang bertujuan untuk lebih banyak memberikan bekal bagi Narapidana dalam menyongsong kehidupan setelah selesai menjalani masa hukuman (bebas). Pemasyarakatan dinyatakan sebagai suatu sistem pembinaan terhadap para pelanggar hukum yang bertujuan untuk mencapai reintegrasi sosial atau pulihnya kesatuan hubungan antara Warga Binaan Pemasyarakatan dengan masyarakat.

Pembinaan narapida adalah sebuah sistem.Ada tiga sistem yang biasa diperbandingkan, pertama adalah sistem kepenjaraan, kedua adalah sistem pemasyarakatan dan ketiga adalah sistem pemasyarakatan baru. ${ }^{2}$ Dalam sistem kepenjaraan, pemasyarakatan dan masyarakatan baru telah terjadi kodifikasi hukum, yang berlaku universal.Pemilihan ketiga sistem tersebut, karena dengan mengambil dua sistem sebelumnya dapat diperoleh perbandingan yang akurat dan dapat dipertanggungjawabkan.

Pembinaan narapidana dikenal dengan nama pemasyarakatan, ada gagasan merubah tujuan pembinaan narapidana dari sistem kepenjaraan ke sistem pemasyarakatan. Pendekatan terhadap narapidana saat masih lembaga kepenjaraan menekankan security approach, sedangkan dalam sistem pemasyarakatan

\footnotetext{
${ }^{1}$ Nashriana, 2011, Perlindungan Hukum Pidana Bagi Anak di Indonesia, PT Raja Grafindo Persada, Jakarta, hlm. 154.

${ }^{2}$ Harsono, 1995, Sistem Baru Pembinan Narapidana, Djambatan, Jakarta, hlm. 6

Pelaksanaan Tugas Pembimbing Kemasyarakatan Dalam Proses Diversi Anak Yang

Berkonflik Dengan Hukum di Balai Pemasyarakatan Kelas 1

Oleh : Ica Karina 
digunakan pendekatan pembinaan (treatment approach). ${ }^{3}$ Dalam pembinaan ada beberapa komponen pembinaan yaitu pembinaan, yang dibina, materi pembinaan, tempat pembinaan, sarana pembinaan, dan sejumlah komponen lainnya.Narapidana adalah subjek sekaligus objek pembinaan.Pertumbuhan pembinaan seharusnya berangkat dari bawah (bottom up) sebagai bagian dari sistem pembinaan narapidana.Bottom up approach adalah pembinaan narapidana yang berdasarkan kebutuhan belajar narapidana. ${ }^{4}$ Tidaklah sulit memenuhi kebutuhan belajar narapidana, sekalipun jumlah jenis kebutuhannya bermacam-macam. Dari skala prioritas dapat ditentukan jenis pembinaan, dengan memperhitungkan lama tiap jenis pembinaan dengan lama pidana yang dijalani setiap narapidana.

Pembinaan narapidana tidak hanya pembinaan mental-spiritual saja (pembinaan kemandirian), tetapi juga pemberian pekerjaan selama berada di lembaga pemasyarakatan (pembinaan keterampilan). Pelaksanaan pembinaan dalam sistem pemasyarakatan pada prinsip yang terdiri atas dua bagian yaitu intramural treatment dan ekstramural treatment. ${ }^{5}$ Intramural treatment artinya pembinaan terebut dilaksanakan di dalam lembaga pemasyarakatan dengan tujuan memperbaiki dan meningkatkan ketaqwaan terhadap Tuhan Yang Maha Esa, intelektual, sikap dan perilaku, kesehatan jasmani dan rohani. ${ }^{6}$

Lembaga Pemasyarakatan (Lapas) ialah tempat melaksanakan pembinaan narapidana dan anak didik pemasyarakatan sebagai salah satu unit pelaksanan teknis (UPT) pemasyarakatan. Secara umum lembaga permasyarakatan memiliki sarana dan prasarana fisik yang cukup memadai bagi pelaksanan pembinaan naapidana, seperti adanya sarana perkantoran, sarana perawatan (balai pengobatan), sarana peribadatan, sarana pendidikan dan perpustakaan (hanya pada beberapa lapas), sarana kerja terdiri dari bengkel kerja dan tanah pertanian, sarana olahraga baik berupa lapangan voli, bulu tangkis, tenis meja maupun lapangan sepak bola, sarana sosial terdiri dari tempat kunjungan keluarga, aula pertemuan dan ruang konsultasi, sarana transportasi (mobil dinas). Jika dilihat perlakuan narapidana

\footnotetext{
${ }^{3}$ Josias Simon, 2012, Studi Kebudayaan Lembaga Kemasyarakatan di Indonesia, Lubuk Agung, Bandung, hlm 13

${ }^{4}$ Harsono, Op.cit., hlm 22

5 Ibid, hlm 21

${ }^{6}$ Ibid
}

Pelaksanaan Tugas Pembimbing Kemasyarakatan Dalam Proses Diversi Anak Yang Berkonflik Dengan Hukum di Balai Pemasyarakatan Kelas 1

Oleh : Ica Karina 
dalam Lapas terutama menu makanan yang diberikan, bermacam makanan diberikan selama 7 hari dari senin sampai minggu, selama tiga kali pagi, siang dan sore. Isi menunya bervariasi, makanan pokoknya ada nasi putih (bubur beras), sayur, tempe, tahu, ubi, ikan asin, dan air minum.

Bentuk bimbingan yang diberikan berupa : pendidikan agama, pendidikan budi pekerti, bimbingan dan penyuluhan perorangan maupun kelompok, pendidikan formal, kepramukaan, pendidikan keterampilan kerja, psikoterapi, kepustakaan, dan psikiatri terapi. Wujud pembimbingan yang diberikan kepada Klien didasarkan pada masalah dan kebutuhan Klien pada saat sekarang dan masa mendatang yang diselaraskan dengan kehidupan keluarga dan lingkungan masyarakat. Dengan demikian jika warga binaan di Lembaga Pemasyarakatan kelak bebas dari hukuman, mereka dapat diterima kembali oleh masyarakat dan lingkungannya dan dapat hidup secara wajar seperti sediakala. Fungsi Pemidanaan tidak lagi sekedar penjeraan tetapi juga merupakan suatu proses rehabilitasi dan reintegrasi sosial Warga Binaan yang ada di dalam lembaga pemasyarakatan. Tentu saja hal ini sangat kontradiktif apabila dibandingkan dengan visi dan misi pemasyaratan sebagai tempat pembinaan narapidana, agar keberadaannya dapat diterima kembali oleh masyarakat sewaktu bebas.

\section{B. PERMASALAHAN}

Berdasarkan hal tersebut di atas, maka Penulis merumuskan beberapa hal penting yang dianggap sebagai permasalahan yang akan menjadi titik tolak pembahasan dalam penelitian, yaitu sebagai berikut:

1. Bagaimana tugas pembimbing kemasyarakatan terhadap anak yang berhadapan dengan hukum?

2. Bagaimana pelaksanaan pembimbing kemasyarakatan dalam proses diversi terhadap anak yang berhadapan dengan hukum?

\section{PEMBAHASAN}

Fungsi hukum sebagai pengendalian sosial (a tool of social control) untuk memperbaiki tingkah laku anak, ${ }^{7}$ yang mana dianggap menyimpang terhadap aturan hukum hingga mempermudah tindakan atau sanksi apa yang tepat dalam

\footnotetext{
${ }^{7}$ Achmad Ali, 1996, Tabir Hukum, Suatu Kajian Filosofis dan Sosilogis, Toko Agung,Jakarta, hlm. 87.

Pelaksanaan Tugas Pembimbing Kemasyarakatan Dalam Proses Diversi Anak Yang Berkonflik Dengan Hukum di Balai Pemasyarakatan Kelas 1

Oleh : Ica Karina 
memulihkan anak. Hukum responsif lebih jelas memaparkan ilmu hukum yang menggunakan pendekatan sosiologis (sociological jurisprudence) untuk memberikan kemampuan bagi institusi hukum untuk secara lebih menyeluruh dan cerdas mempertimbangkan fakta sosial yang disitu hukum berproses dan diaplikasikan. ${ }^{8}$ Konsep diversi merupakan bentuk pengalihan satu kasus dari formal ke proses informal. ${ }^{9}$ Sebagaimana teori diversi merupakan upaya guna menekankan pengalihan penyelesaian perkara anak dari proses peradilan ke proses di luar peradilan pidana. Anak bisa terhindar atau dijauhkan dari proses peradilan guna melindungi anak dari stigmatisasi bagi anak yang berhadapan dengan hukum guna dikembalikan kelingkungan sosialnya secara wajar. Konsep perlindungan anak sebagaimana dimandatkan dalam Pasal 64 ayat (1) Undang-Undang Perlindungan Anak, memberi mandat pada anak-anak yang berkonflik dengan hukum dan anak korban tindak pidana. Pencapaian Keadilan Restoratif adalah penyelesaian perkara tindak pidana dengan melibatkan pelaku, korban, keluarga pelaku/korban, dan pihak lain yang terkait untuk bersama-sama mencari penyelesaian yang adil dengan menekankan pemulihan kembali pada keadaan semula, dan bukan pembalasan. Upaya pendekatan restorative justice merupakan suatu pendekatan yang menitikberatkan terciptanya keadilan dan keseimbangan antara pelaku tindak pidana dengan korbannya sendiri.

\section{Tugas Pembimbing Kemasyarakatan Terhadap Anak Yang Berkonflik Dengan Hukum}

Dalam Keputusan Menteri Kehakiman RI Nomor M.01-PK.04.10 Tahun 1998 tentang Tugas, Kewajiban, dan Syarat-Syarat bagi Pembimbing Kemasyarakatan dijelaskan bahwa tugas pembimbing kemasyarakatan adalah sebagai berikut: ${ }^{10}$

1. Melakukan penelitian kemasyarakatan untuk:

a. Membantu tugas penyidik, penuntut umum, dan hakim dalam perkara anak nakal, (Pasal ini sudah diamandemen menjadi "pembimbing" kemasyarakatan bukan lagi hanya sebagai "pembantu", tetapi

\footnotetext{
${ }^{8}$ Philippe Nonet dan Philip Selznick, 2011, Hukum Responsif, Nusa Media, Medan, hlm. 83.

${ }^{9}$ Ibid

${ }^{10}$ Keputusan Menteri Kehakiman RI Nomor M.01-PK.04.10 Tahun 1998 tentang Tugas, Kewajiban, dan Syarat-Syarat bagi Pembimbing Kemasyarakatan

Pelaksanaan Tugas Pembimbing Kemasyarakatan Dalam Proses Diversi Anak Yang Berkonflik Dengan Hukum di Balai Pemasyarakatan Kelas 1

Oleh : Ica Karina 
statusnya sama-sama sebagai penegak hukum yang masing-masing mempunyai tugas khusus);

b. menentukan program pembinaan narapidana di lapas dan anak didik pemasyarakatan di lapas anak;

c. menentukan program perawatan tahanan di rutan;

d. menentukan program bimbingan dan/atau bimbingan tambahan bagi klien pemasyarakatan.

2. Melaksanakan bimbingan kemasyarakatan dan bimbingan kerja bagi klien pemasyarakatan;

3. Memberikan pelayanan terhadap instansi lain dan masyarakat yang meminta data atau hasil penelitian kemasyarakatan klien tertentu;

4. Mengkoordinasikan pembimbing kemasyarakatan dan pekerja sukarela yang melaksanakan tugas pembimbingan; dan

5. Melaksanakan pengawasan terhadap terpidana anak yang dijatuhi pidana pengawasan, anak didik pemasyarakatan yang diserahkan kepada orang tua, wali atau orang tua asuh yang diberi tugas pembimbingan.

Adapun Tugas Pembimbing Kemasyarakatan dalam pembuatan penelitian kemasyarakatan (atau selanjutnya disebut LITMAS) dan pendampingan anak yang berkonflik dengan hukum selaku tersangka / terdakwa dalam proses peradilan pidana anak, dan untuk tersangka dewasa dalam tindak pidana tertentu serta LITMAS untuk kepentingan perawatan tahanan dan pembinaan narapidana menunjukkan keterlibatan Pembimbing Kemasyarakatan sejak awal proses hukum hingga kembalinya seorang narapidana dan anak didik pemasyarakatan kepada masyarakat. ${ }^{11}$

Tugas Pembimbing Kemasyarakatan di Balai Pemasyarakatan Kelas I Medan: ${ }^{12}$

1. Menyusun Litmas

2. Melaksanakan proses Diversi bersama aparat lain

${ }^{11}$ Ibid

Pelaksanaan Tugas Pembimbing Kemasyarakatan Dalam Proses Diversi Anak Yang Berkonflik Dengan Hukum di Balai Pemasyarakatan Kelas 1

Oleh : Ica Karina 
3. Melakukan pendampingan, pembimbingan, dan pengawasan selama proses Diversi berlangsung sampai dengan kesepakatan Diversi dilaksanakan

4. Melaporkan kepada pejabat yang bertanggung jawab bila kesepakatan Diversi tidak dilaksanakan dalam waktu yang ditentukan

5. Melaksanakan pengawasan terhadap terpidana anak yang dijatuhi pidana pengawasan, anak didik pemasyarakatan yang diserahkan kepada orang tua, wali atau orang tua asuh dan orang tua, wali dan orang tua asuh yang diberikan tugas pembimbingan

Fungsi pembimbing kemasyarakatan di Balai Pemasyarakatan (Bapas) Kelas I Medan dalam melaksanakan program bimbingan terhadap klien adalah untuk: $:^{13}$

1. menyadarkan klien untuk tidak melakukan kembali pelanggaran hukum/tindak pidana;

2. menasihati klien untuk selalu dapat menyesuaikan diri dengan lingkungan yang positif/baik;

3. menghubungi dan melakukan kerja sama dengan pihak ketiga/pihak tertentu dalam menyalurkan bakat dan minat klien sebagai tenaga kerja, untuk kesejahteraan masa depan dari klien tersebut.

Kewajiban Pembimbing Kemasyarakatan di Balai Pemasyarakatan (Bapas)

Kelas I Medan : $:^{14}$

1. Menyusun laporan atas hasil penelitian kemasyarakatan yang telah dilakukannya;

2. Mengikuti sidang Tim Pengamat Pemasyarakatan guna memberikan data, saran dan pertimbangan atas hasil penelitian dan pengamatan yang telah dilakukannya;

3. Mengikuti sidang pengadilan yang memeriksa perkara Anak Nakal guna memberikan penjelasan, saran dan pertimbangan kepada hakim mengenai segala sesuatu yang berkaitan dengan Anak Nakal yang sedang diperiksa di Pengadilan berdasarkan hasil penelitian kemasyarakatan yang telah dilakukannya;

4. Melaporkan setiap pelaksanaan tugas kepada Kepala BAPAS.

Lemahnya konsep penghukuman dimana pemenjaraan sebagai alat penjeraan dipandang gagal dapat dilihat dari $:{ }^{15}$

13 Ibid

${ }^{14}$ Ibid

${ }^{15}$ Harsono, Op.cit., hlm 22.

Pelaksanaan Tugas Pembimbing Kemasyarakatan Dalam Proses Diversi Anak Yang Berkonflik Dengan Hukum di Balai Pemasyarakatan Kelas 1

Oleh : Ica Karina 
1. Penjara tidak mengurangi angka kriminalitas;

2. Penjara melahirkan residivisme;

3. Penjara tidak pernah gagal melahirkan orang yang menyimpang;

4. Penjara memungkinkan bahkan menyokong lahirnya organisasi penyimpangan yang loyal antara yang satu dengan yang lainnya, terhirarkhi siap untuk saling membantu tindakan kriminal di masa depan

5. Kondisi dimana narapidana yang telah dibebaskan acapkali dilabeli dengan residivisme;

6. Penjara tidak langsung menghasilkan orang yang menyimpang dengan mengabaikan keluarga narapidana kedalam lembah kemiskinan.

\section{Pelaksanaan Pmbimbing Kemasyarakatan Dalam Proses Diversi Terhadap}

\section{Anak Yang Berkonflik Dengan Hukum}

Proses diversi pada dasarnya merupakan upaya pengalihan dari proses peradilan pidana menuju penyelesaian secara musyawarah, yang pada dasarnya merupakan jiwa dari bangsa Indonesia, untuk menyelesaikan permasalahan dengan cara kekeluargaan untuk mencapai mufakat. Hal ini sesuai dengan bunyi Sila ke-4 Pancasila yang berbunyi “Kerakyatan yang Dipimpin oleh Hikmat Kebijaksanaan dalam Permusyawaratan/Perwakilan”. Diversi hanya dilaksanakan dalam hal tindak pidana yang dilakukan itu diancam dengan pidana penjara di bawah 7 (tujuh) tahun dan bukan merupakan pengulangan tindak pidana" Sedangkan penahanan terhadap anak hanya dilakukan jika anak telah berumur 14 (empat belas) tahun atau lebih dan diduga melakukan tindak pidana dengan ancaman pidana penjara 7 (tujuh) tahun atau lebih. Ini artinya, merujuk pada syarat mengenai ancaman pidana dalam pelaksanaan diversi dan penahanan, bagi anak yang terhadapnya dilakukan diversi, terhadapnya tidak dilakukan penahanan.

Adapun jumlah pembimbing klien anak di Balai Pemasyarakatan Anak di Kelas I Medan terdiri dari 13 orang, antara lainnya adalah

a. Kasie Bimb. Klien Anak (1 orang)

b. Kasubsi Registrasi (5 orang)

c. Kasubsi Bimb. Kemasyarakatan (4 orang)

Pelaksanaan Tugas Pembimbing Kemasyarakatan Dalam Proses Diversi Anak Yang Berkonflik Dengan Hukum di Balai Pemasyarakatan Kelas 1

Oleh : Ica Karina 
d. Kasubsi Bimb. Kerja (3 orang).

Pelaksanaan sistem Pemasyarakatan mempunyai tujuan akhir yaitu terciptanya kemandirian warga binaan Pemasyarakatan atau membangun manusia mandiri. Sistem Peradilan pidana dalam kerangka system merupakan rangkaian kegiatan yang dilakukan dalam rangka menegakkan hukum pidana dan menjaga ketertiban sosial, dilaksanakan mulai kerja polisi dalam melakukan penyidikan peristiwa pidana, penuntutan oleh Jaksa Penuntut Umum, Pemeriksaan perkara di pengadilan dan pelaksanaan hukuman di Lapas, Rutan dan Cabang Rutan. Salah satu kegiatan dalam rangkaian kegiatan system peradilan pidana tersebut dilaksanakan oleh Balai Pemasyarakatan (BAPAS) yang merupakan bagian dari kegiatan sub sistem pemasyarakatan narapidana atau sub-sub system peradilan pidana dimana Balai Pemasyarakatan (BAPAS) merupakan bagian dari system

Tata Peradilan, mempunyai tugas melaksanakan pembimbing dan mendampingi anak nakal dlam proses Peradilan Anak. Permasalahan anak yang berkonflik dengan hukum membutuhkan peranan pembimbing kemasyarakatan dalam mendampingi mereka.Pembimbing kemasyarakatan sebagai seorang pendamping harus menempatkan dirinya sebagai sahabat anak dan menempatkan anak sebagaimanusia yang pantas untuk dihormati serta memiliki hak-hak, bukan hanya perlindungan hukum tetapi juga perlindungan sosial.Untuk memenuhi perlindungan tersebut pembimbing kemasyarakatanmelalui kerjasama dengan pengacara menuntut aparat penegak hukum untuk menghindarkan penyiksaan terhadap anak.pembimbing kemasyarakatanharus melakukan kunjungan rutin kepada anak ketika anak berada dalam tahanan atau penjara dan memberikan kesempatan yang seluas-luasnya kepada anak untuk mengemukakan pendapatnya dan mengekspresikan dirinya secara bebas (Pasal 12 dan Pasal 13 Konvensi Hak Anak).

Pengaturan Sistem Peradilan Pidana Anak (SPPA) mempertegas pengaturan terhadap konsep diversi. Mempertegas penghindaran dan upaya terakhir terhadap penjauhan anak dari proses peradilan, sehingga dapat menghindari stigmatisasi terhadap anak yang berkonflik dengan hukum dan diharapkan anak dapat kembali kedalam lingkungan sosial secara wajar. Pengalihan penyelesaian perkara anak dari proses peradilan pidana ke proses di luar peradilan pidana, harus dilandasi semangat 
pencapaian penyelesaian dengan melibatkan pelaku, korban, keluarga pelaku/korban, dan pihak lain yang terkait untuk bersama-sama mencari penyelesaian yang adil dengan menekankan pemulihan kembali pada keadaan semula yang bukan pembalasan.

Keadilan restoratif yang dimaksud kewajiban melaksanakan Diversi. Diversi merupakan pengalihan penyelesaian perkara Anak dari proses peradilan pidana ke proses di luar peradilan pidana. Diversi yang berfungsi agar anak yang berhadapan dengan hukum tidak terstigmatisasi akibat proses peradilan yang harus dijalaninya. Penggunaan mekanisme diversi tersebut diberikan kepada para penegak hukum (Polisi, Jaksa, Hakim, Lembaga lainnya) dalam menangani pelanggar-pelanggar hukum yang melibatkan anak tanpa menggunakan pengadilan formal. Penerapan Diversi tersebut dimaksudkan untuk mengurangi dampak negatif keterlibatan anak dalam suatu proses peradilan.

Pencapaian pengalihan penyelesaian perkara pidana anak dalam ranah di luar peradilan pidana (diversi) Pasal 1 ayat (7) dan (6) UU No. 11 Tahun 2012 tentang Sistem Peradilan Pidana Anak. bertujuan :

1. Mencapai perdamaian antara korban dan anak,

2. Menyelesaikan perkara Anak di luar proses peradilan,

3. Menghindarkan Anak dari perampasan kemerdekaan,

4. Mendorong masyarakat untuk berpartisipasi, dan,

5. Menanamkan rasa tanggung jawab kepada anak.

Musyawarah penyelesaian sebagaimana mandat dengan melibatkan para pihak yakni anak dan orang tua/walinya, korban dan/atau orang tua/walinya, korban dan atau orang tua/walinya, pembimbing kemasyarakatan, dan pekerja sosial profesional harus berdasarkan pendekatan keadilan restoratif. Pasal 8 ayat (2) Undang-Undang No. 11 Tahun 2012 tentang Sistem Peradilan Pidana Anak sebagaimana hal tersebut harus dilandasi dengan memperhatikan:

1. Kepentingan korban,

2. Kesejahteraan dan tanggung jawab anak,

3. Penghindaraan stigma negative,

4. Penghindaraan pembalasan,

5. Keharmonisan masyarakat,

6. Kepatutan, kesusilaan, dan ketertiban umum.

Masing-masing pihak dalam setiap tingkatan sebagai fasilitator, dalam melakukan upaya mediasi perdamaian. Pasal 10 ayat (2) Undang-Undang No. 11 Pelaksanaan Tugas Pembimbing Kemasyarakatan Dalam Proses Diversi Anak Yang Berkonflik Dengan Hukum di Balai Pemasyarakatan Kelas 1 
Tahun 2012 tentang Sistem Peradilan Pidana Anak sebagaimana upaya musyawarah atau pencapaian kesepakatan dapat dilakukan setelah adanya rekomendasi dari pembimbing kemasyarakatan dalam bentuk:

1. Pengembalian kerugian dalam hal ada korban,

2. Rehabilitasi medis dan psikososial,

3. Penyerahaan kembali kepada orang tua/wali,

4. Keikutsertaan dalam pendidikan atau LPKS paling lama 3 (tiga) bulan,

5. Pelayanan masyarakat paling lama 3 (tiga) bulan.

Balai pemasyarakatan di Bapas Kelas I Medan menerapkan model pendekatan untuk tiga tahapTahap penyidikan di Kepolisian: Pembimbing Kemasyarakatan berupaya melakukan mediasi dengan melibatkan keluarga, pihak korban, dan masyarakat setempat,

1. Tahap pengadilan anak: Pembimbing Kemasyarakatan mendampingi anak selama proses pengadilan dan berkoordinasi dengan Lembaga Bantuan Hukum (LBH),

2. Tahap penyidikan maupun setelah putusan hakim: Pembimbing Kemasyarakatan berkoordinasi dengan panti sosial.

Tahap-tahap pelaksanaan diversi dalam Sistem Peradilan Pidana Anak, antara lain: ${ }^{16}$

1. Tahap-tahap Pelaksanaan Diversi Dalam Proses Penyidikan Ketika penyidik menerima laporan adanya tindak pidana, maka langkah yang diambil adalah melakukan penyelidikan serta penyidikan. Kemudian penyidik akan menghubungi pihak Balai Pemasyarakatan (Bapas) untuk berkoordinasi. Pihak Bapas akan membuat laporan penelitian masyarakat dan memberikan saran kepada penyidik untuk melakukan diversi. Atas saran dari Bapas, penyidik akan memfasilitasi untuk melakukan diversi.

2. Tahap-tahap Pelaksanaan Diversi Dalam Proses Penuntutan Pada tahap penuntutan, penuntut umum wajib mengupayakan diversi paling lama 7 hari setelah menerima berkas perkara dari penyidik. Proses diversi akan dilaksanakan paling lama 30 hari. Pada proses diversi, akan dilakukan musyawarah antara anak beserta orang tua atau walinya, korban beserta orang tua atau walinya, pembimbing masyarakat, dan pekerja sosial profesional.

3. Tahap-tahap Pelaksanaan Diversi Dalam Proses Persidangan Dalam tahap persidangan, ketua pengadilan wajib menetapkan Hakim atau majelis hakim untuk menangani perkara Anak paling lama 3 hari setelah menerima berkas perkara dari penuntut umum. Hakim wajib mengupayakan diversi paling lama 7 hari setelah ditetapkan oleh ketua pengadilan negeri sebagai hakim. Diversi dilaksanakan paling lama 30 hari.

\footnotetext{
${ }^{16}$ Angger Sigit Pramukti dan Fuady Primaharsya, 2015, Sistem Peradilan Pidana Anak, Pustaka Yustisia, Yogyakarta, hlm. 70.

Pelaksanaan Tugas Pembimbing Kemasyarakatan Dalam Proses Diversi Anak Yang Berkonflik Dengan Hukum di Balai Pemasyarakatan Kelas 1

Oleh : Ica Karina 
Setelah jatuh keputusan bahwa anak berkonflik dengan hukum mendapatkan tindakan dan/atau Pidana, pihak-pihak terkait akan mengawasi dan membantu anak yang berkonflik dengan hukum hingga langkah ketiga, yakni reintegrasi. Mereka memastikan bahwa anak yang berkonflik dengan hukum dapat menyatu kembali ke dalam masyarakat seperti sedia kala.

\section{KESIMPULAN}

1. Tugas Pembimbing Kemasyarakatan dalam pembuatan penelitian kemasyarakatan dan pendampingan anak yang berkonflik dengan hukum selaku tersangka / terdakwa dalam proses peradilan pidana anak, dan untuk tersangka dewasa dalam tindak pidana tertentu serta LITMAS untuk kepentingan perawatan tahanan dan pembinaan narapidana menunjukkan keterlibatan Pembimbing Kemasyarakatan sejak awal proses hukum hingga kembalinya seorang narapidana dan anak didik pemasyarakatan kepada masyarakat.Secara garis besar, tugas utama pembimbing kemasyarakatan adalah membuat laporan hasil penelitian kemasyarakatan untuk kepentingan penyidikan, penuntutan, dan persidangan dalam perkara anak, melakukan pendampingan, melakukan pembimbingan, dan melakukan pengawasan terhadap anak selama proses diversi dan pelaksanaan kesepakatan.

2. Dalam pelakanaannya pembimbing kemasyarakatan Kelas I Medan mempunyai tugas dan fungsi, antara lain tugas pokok pembimbing kemasyarakatan Bapas Kelas I Medan adalah memberikan bimbingan kemasyarakatan atau pengentasan anak sesuai dengan peraturan perundangundangan yang berlaku dan Melaksanakan pembinaan, bimbingan dan pengawasan terhadap klien di luar Lembaga Pemasyarakatan. Adapun Fungsi pembimbing kemasyarakatan adalah melakukan penelitian kemasyarakatan (Litmas)sebagai bahan pada sidang pengadilan anak berdasarkan permintaan pihak kepolisian, kejaksaan, pengadilan atau Bapas lain, melakukan litmas sebagai bahan pertimbangan program pembinaan Warga BinaanPemasyarakatan berdasarkan permintaan dari Lapas, Rutan atau Bapas lain, melakukan registrasi klien pemasyarakatan, Melakukan bimbingan kemasyarakatan dan pengentasan anak, mengikuti sidang Pelaksanaan Tugas Pembimbing Kemasyarakatan Dalam Proses Diversi Anak Yang Berkonflik Dengan Hukum di Balai Pemasyarakatan Kelas 1 
pengadilan di pengadilan negeri dan sidang TPP di Bapas, Lapas atau Rutan sesuai dengan peraturan perundang-undangan berlaku, menyelenggarakan bimbingan (mental,sosial dan latihan kerja) baik yang diselenggarakan sendiri maupun instansi lain, melaksanakan urusan tata usaha Balai Pemasyarakatan. Pembimbing kemasyarakatan Kelas I Medan melaksanakan tugas dan fungsinya terhadap anak yang berhadapan dengan hukum. Dalam Proses penanganan anak, setiap pembimbing kemasyarakatan di Balai Pemasyarakatan Kelas I Medan harus memenuhi tugas dan fungsinya.

\section{E. SARAN}

1. Supaya Koordinasi antar lembaga yang menangani masalah anak yang berhadapan dengan hukum dapat berjalan dengan baik. Koordinasi yang buruk berpotensi gagalnya dilaksanakan diversi terhadap anak yang berhadapan dengan hukum. Kirannya adanya tentang pemahaman diversi. Terlaksananya diversi sangat dipengaruhi oleh kesediaan pihak korban namun untuk menentukan kesepakatan antara pihak korban dan anak yang berhadapan dengan hukum tidaklah mudah. Perbedaan kepentingan antara keduanya merupakan masalah mendasar dalam penentuan kesepakatan, terkadang permintaan pihak korban tidak dapat dipenuhi oleh anak yang berhadapan dengan hukum namun pihak korbanpun tidak ingin mengubah persyaratan kesepakatannya sehingga pelaksanaan diversi gagal dilakukan.

2. Terkait meningkatnya tuntutan masyarakat terhadap tugas-tugas kemasyarakatan yang lebih baik tugas dan tanggung jawab Pembimbing Kemasyarakatan harus mampu mengoptimalkan perannya lebih aktif pada proses peradilan sejak tahap pra adjudikasi, adjudikasi dan post adjudikasi. Kompleksitas tugas Pembimbing Kemasyarakatan tentu membutuhkan sosok petugas yang memiliki kapabilitas dan profesionalisme yang tinggi karena dalam pelaksanaan tugasnya, Pembimbing Kemasyarakatan menghadapi berbagai pihak dari berbagai golongan dan latar belakang. Lengkapnya permasalahan di lingkungan Pemasyarakatan dimana over kapasitas di setiap Lembaga Pemasyarakatan maupun Rutan, terbatasnya 
SDM serta persoalan keberadaan barang terlarang menjadi tantangan dan pekerjaan rumah bagi Kementerian Hukum dan HAM.

\section{DAFTAR PUSTAKA}

Ali, Achmad, Menguak Tabir Hukum,1996 Suatu Kajian Filosofis dan Sosilogis, PT. Toko Agung, Jakarta.

Harsono, 1995, Sistem Baru Pembinan Narapidana, Djambatan, Jakarta.

Nashriana, 2011, Perlindungan Hukum Pidana Bagi Anak di Indonesia, PT Raja Grafindo Persada, Jakarta.

Nonet, Philippe dan Philip Selznick, 2011, Hukum Responsif, Nusa Media, Medan. Simon, Josias, 2012, Studi Kebudayaan Lembaga Kemasyarakatan di Indonesia, Lubuk Agung, Bandung.

Keputusan Menteri Kehakiman RI Nomor M.01-PK.04.10 Tahun 1998 tentang Tugas, Kewajiban, dan Syarat-Syarat bagi Pembimbing Kemasyarakatan Republik Indonesia, Undang-Undang Nomor 11 Tahun 2012 tentang Sistem Peradilan Pidana Anak

---------------, Undang-Undang Nomor 35 Tahun 2014 tentang Perubahan atas Undang-Undang Nomor 23 Tahun 2002 tentang Perlindungan Anak 